\title{
Degradation of Transgene RNA in Virus-resistant Transgenic Plants Expressing Catalytic Antisense RNA against Virus Genome
}

\author{
Shigeo NAKAmURA*, Takayoshi IWAI*, Ryoso HonkURA*, \\ Masashi UGAKI** and Yuko OHASHI**
}

Key words : transgenic plant, virus resistance, transgene inactivation.

\begin{abstract}
Since the demonstration that the transgenic plants expressing tobacco mosaic virus (TMV) coat protein (CP) gene showed resistance to TMV infection ${ }^{9)}$, there have been numerous attempts to produce virus-resistant plants by introducing of a part of or modified viral genome, such as $\mathrm{CP}$, movement protein and viral polymerase genes, and of virus-targeted sequence, antisense and ribozyme ${ }^{13)}$. The mechanisms of viral genome-derived or virus-targeted resistance, however, remained unknown.
\end{abstract}

In the case of CP-mediated resistance, the degrees of resistance are not always correlated to the levels of $\mathrm{CP}$ expression, so that re-encapsidation theory cannot adequately explain the events ${ }^{12)}$. Lindbo et al. ${ }^{6)}$ reported that transgenic plants expressing the tobacco etch virus (TEV) CP were initially susceptible but later recovered from TEV infection. This "recovery" phenomenon did not depend on a translocatable signal and was observed at a single cell level. Although steady-state levels of the transgene RNA in recovered tissue were 12-22 fold less than that in uninoculated tissue, the transcription rate in recovered and uninoculated plants were similar. Thus, they proposed that the resistance state and reduced steady-state levels of transgene RNA accumulation were mediated by a cytoplasmic activity of targeted RNA elimination.

We have already reported that transgenic tobacco plants expressing catalytic antisense RNA against cucumber mosaic virus (CMV) 3a gene showed resistance to $\mathrm{CMV}$ infection ${ }^{8}$. In that report, the degree of resistance in catalytic antisense RNA-expressing R1 plants did not so strongly influenced by the concentrations of inocula as in CP-expressing plants, and various degrees of resistance were observed in progeny from the same parent. To elucidate the resistance mechanism, we investigated the relationship 'among symptom development, virus accumulation and expression levels of transgene, and we found that catalytic antisense RNAmediated resistance did not directly depend on the steady-state levels of transgene RNA. Moreover, we had the evidence that the targeted elimination of transgene RNA was induced in CMV-resistant transformants.
Catalytic antisense RNA-expressing transgenic plants were previously reported ${ }^{8)}$. The most resistant R1 line, Rz204, were inoculated with $10 \mu \mathrm{g} / \mathrm{ml} \mathrm{CMV-Y.} \mathrm{Eight}$ plants showing no systemic symptoms out of 36 plants inoculated were self-fertilized. One of R2 lines, Rz204-1, were used for inoculation experiments. Forty seedlings of kanamycin resistant Rz204-1 were grown in a growth room at $26^{\circ} \mathrm{C}$ (day) $/ 22^{\circ} \mathrm{C}$ (night) and inoculated with 1 : 100 dilution of CMV-infected tobacco sap on the 6th leaves at the stage of their full expansion. Symptom development on the respective leaves was recorded up to 12 days after inoculation. R1 plants transformed with firefly luciferase gene were used as control.

To assess the accumulation of CMV, four leaf discs (10 $\mathrm{mm}$ i.d.) were harvested from the inoculated (6th) and the upper (7 to 11th) non-inoculated leaves 8 days after inoculation, and then indirect enzyme-linked immunosorbent assay (ELISA) was carried out essentially as described by Hammond and Lawson ${ }^{5}$.

Total RNA was isolated from the transgenic plants by acid guanidium thiocyanate/phenol-chloroform methods $^{1)}$. Ten $\mu \mathrm{g}$ RNA was denatured and separated on a $1.5 \%$ agarose gel under $0.67 \mathrm{M}$ formaldehydedenaturing conditions, and was transferred to a nylon membrane (Hybond-N, Amersham) ${ }^{10)}$. Northern hybridization was performed by a digoxigenin system (Boehringer Mannheim) using the $3 \mathrm{a}$-coding sequence (840 bp) of CMV as a probe. The oligonucleotide corresponding to the $5^{\prime}$-untranslatable sequence of TMV RNA, which was originated from an expression vector $\mathrm{pBE} 2113^{7)}$ and specific to the transgene, was used for the detection of the transgene RNA from CMV-infected tissues.

Responses of Rz204-1 plants to CMV infection were classified into two phenotypes; "susceptible"; showing attenuated systemic symptoms in comparison with control plants and "resistant"; showing mosaic or necrosis on the inoculated leaves but no or slight symptoms on the upper non-inoculated leaves (Table 1). Of 40 plants inoculated, 8 plants were classified into the susceptible phenotype and the remaining 32 plants displayed the resistant phenotype. Although all of them were originated from one transformant, Rz204-1, a wide variety of

\footnotetext{
* Miyagi Prefecture Agricultural Research Center, Takadate-kawakami, Natori 981-12, Japan＼cjkstart宮城県農業センター

** National Institute of Agrobiological Resources, Kannondai, Tsukuba 305, Japan 農業生物資源研究所
} 
Table 1. Symptom development and CMV accumulation on the respective leaves of four typical phenotype plants and control plant

\begin{tabular}{|c|c|c|c|c|c|c|c|c|c|}
\hline \multirow{2}{*}{$\begin{array}{l}\text { Resistance phenotype } \\
\text { (Plant number) }\end{array}$} & \multirow{2}{*}{$\begin{array}{c}\text { Leaf } \\
\text { position }\end{array}$} & \multicolumn{7}{|c|}{ Symptom $^{\text {a) }}$ at DAI ${ }^{\mathrm{b})}$} & \multirow{2}{*}{$\begin{array}{l}\text { ELISA }^{\mathrm{c}} \\
\text { at } 8 \mathrm{DAI}\end{array}$} \\
\hline & & 4 & 5 & 6 & 7 & 8 & 10 & 12 & \\
\hline \multirow{6}{*}{$\begin{array}{c}\text { Resistant } \\
\text { (Rz204-1-14) }\end{array}$} & 6 & - & - & - & - & - & - & - & 0.013 \\
\hline & 7 & - & - & - & - & - & - & - & 0.013 \\
\hline & 8 & - & - & - & - & - & - & - & 0.027 \\
\hline & 9 & - & - & - & - & - & - & - & 0.013 \\
\hline & 10 & - & - & - & - & - & - & - & 0.002 \\
\hline & 11 & - & - & - & - & - & - & - & 0.000 \\
\hline \multirow{6}{*}{$\begin{array}{c}\text { Resistant } \\
(\mathrm{Rz} 204-1-12)\end{array}$} & 6 & - & ys & YS & YS & M & $\mathrm{Y}$ & $\mathrm{D}$ & 0.334 \\
\hline & 7 & - & - & - & - & - & - & - & 0.008 \\
\hline & 8 & - & - & - & - & - & - & - & 0.001 \\
\hline & 9 & - & - & - & - & - & - & - & 0.006 \\
\hline & 10 & - & - & - & - & - & - & - & 0.003 \\
\hline & 11 & - & - & - & - & - & - & - & 0.000 \\
\hline \multirow{6}{*}{$\begin{array}{l}\text { Susceptible } \\
(\mathrm{Rz} 204-1-19)\end{array}$} & 6 & - & ys & YS & YS & $\mathrm{M}$ & $\mathrm{Y}$ & $\mathrm{D}$ & 0.455 \\
\hline & 7 & - & - & - & - & - & - & - & 0.030 \\
\hline & 8 & - & - & - & - & - & - & - & 0.038 \\
\hline & 9 & - & - & vy & vy & vy & vy & vy & 0.176 \\
\hline & 10 & - & - & - & - & - & - & vy & 0.139 \\
\hline & 11 & - & - & vy & vy & vy & VY & M & 0.922 \\
\hline \multirow{6}{*}{$\begin{array}{l}\text { Susceptible } \\
\text { (Rz204-1-11) }\end{array}$} & 6 & ys & ys & YS & YS & $\mathrm{M}$ & $\mathrm{Y}$ & $\mathrm{D}$ & 0.721 \\
\hline & 7 & - & - & - & - & - & - & - & 0.006 \\
\hline & 8 & - & vy & vy & VY & VY & VY & M & 1.284 \\
\hline & 9 & - & vy & vy & VY & VY & VY & M & 1.159 \\
\hline & 10 & - & - & vy & VY & VY & VY & M & 1.591 \\
\hline & 11 & - & vy & vy & VY & VY & $\mathrm{M}$ & $\mathrm{M}$ & 1.376 \\
\hline \multirow{6}{*}{ Control } & 6 & ys & ys & YS & YS & $\mathrm{M}$ & $\mathrm{Y}$ & $\mathrm{D}$ & 0.735 \\
\hline & 7 & - & - & - & - & - & - & - & 0.013 \\
\hline & 8 & $\mathrm{~m}$ & $\mathrm{~m}$ & M & M & M & $\mathrm{M}$ & $\mathrm{M}$ & 0.802 \\
\hline & 9 & $\mathrm{~m}$ & $\mathrm{M}$ & $\mathrm{M}$ & M & M & $\mathrm{M}$ & $\mathrm{M}$ & 1.324 \\
\hline & 10 & - & vy & VY & M & M & $\mathrm{M}$ & M & 1.305 \\
\hline & 11 & $\mathrm{~m}$ & $\mathrm{M}$ & $\mathrm{M}$ & $\mathrm{M}$ & M & M & $\mathrm{M}$ & 1.153 \\
\hline
\end{tabular}

a) Abbreviations for symptoms : -, no symptoms ; ys, mild yellow spot; YS, severe yellow spot; m, mild mosaic ; M, severe mosaic; vy, mild vein yellowing; VY, severe vein yellowing ; Y, severe yellowing; D, necrosis.

b) Days after inoculation.

c) ELISA values (absorbance at $405 \mathrm{~nm}$ ).

responses to CMV infection were observed. Virus accumulations on the respective plants at 8 days after inoculation were correlated with their resistant levels. In the resistant plants, virus translocation to the upper leaves was completely prevented. Especially, Rz204-1-14 plant did not show any symptoms on the inoculated leaf and protected from viral infection.

We expected that the degrees of resistance of catalytic antisense RNA-expressing plants depended on their levels of transgene expressed. Thus, total RNA were extracted from the 5 th leaves just before inoculation and were subjected to Northern hybridization using the 3a-coding sequence as a probe. Contrary to our expectation, no correlation between the steady-state levels of the transgene and the degree of resistance was found in the transgenic plants (Fig. 1). If the mechanism of catalytic antisense RNA-mediated resistance was simply involved in digestion of target sequence and/or duplex formation between complementary arms adjacent to catalytic sequence and virus RNA, the degree of resistance would be directly proportional to the expression levels of transgene. Therefore, unknown host responses must be involved in this resistance.

Smith et al. ${ }^{11)}$ reported that an inverse correlation between steady-state levels of transgene RNA and resistance was found in transgenic lines expressing untranslatable potato virus Y (PVY) CP gene. They concluded that the resistance was caused by a cytoplasmic activity targeting specific RNA sequences for inactivation. To confirm whether exogenous RNA degradation occurred in CMV-infected tissues as reported in "recovered" or "highly resistance" plants ${ }^{2,6,11)}$, total RNAs were isolated from the upper leaves 8 days after inoculation, and were subjected to Northern hybridization (Fig. 2B). Trans- 


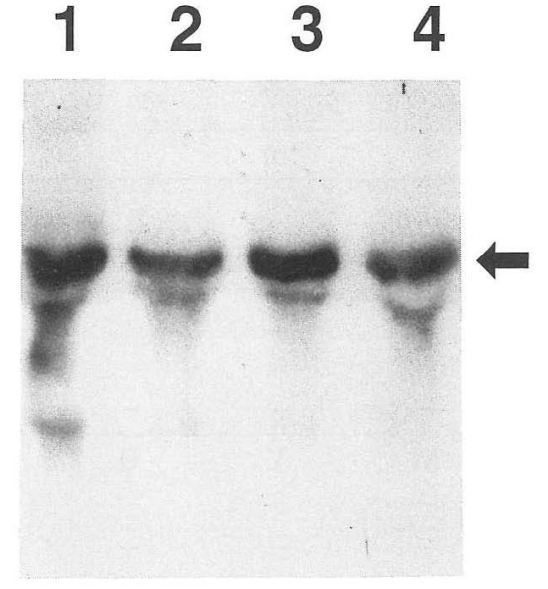

Fig. 1. Northern analysis of total RNA prepared from four typical phenotype plants represented in Table 1, Rz204-1-14 (lane 1), Rz204-1-12 (lane 2), Rz204-1-19 (lane 3) and Rz204-1-11 (lane 4). Total RNA was extracted from the 5 th leaves just before inoculation and then the transgene transcripts were detected with the digoxigeninlabeled probe corresponding to the 3a-coding region. The position corresponding to the intact transgene transcripts is indicated by an arrow.

\section{$\begin{array}{llllllllll}1 & 2 & 3 & 4 & 5 & 6 & 7 & 8 & 9 & 10111213141516\end{array}$}

A

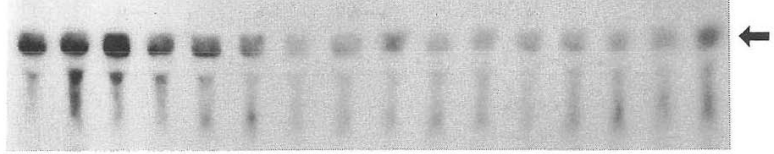

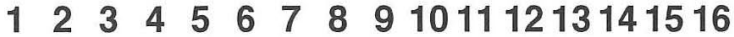

B

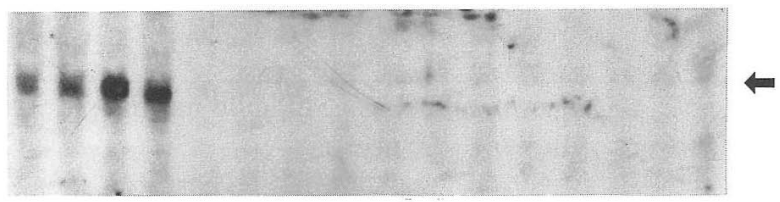

Fig. 2. Northern analysis of total RNA prepared from four susceptible plants (lanes 1-4) and twelve resistant plants (lanes 5-16). Total RNA was extracted from the 5 th leaves just before inoculation $(\mathrm{A})$ and the 8 th leaves 8 days after inoculation (B), and then the transgene transcripts were detected with the digoxigeninlabeled probe corresponding to the 3a-coding region (A) or the oligonucleotides probe complementary to the $5^{\prime}$-untranslatable sequence of the transgene (B). The position corresponding to the intact transgene transcripts is indicated by arrows.

gene RNA could be hardly detected in the resistant plants, although high steady-state levels of the transgene RNA from the susceptible plants were observed. In all of these plants tested, the transgene transcripts with appropriate size were observed just before inoculation (Fig. 2A). This suggests that the transgene transcripts were

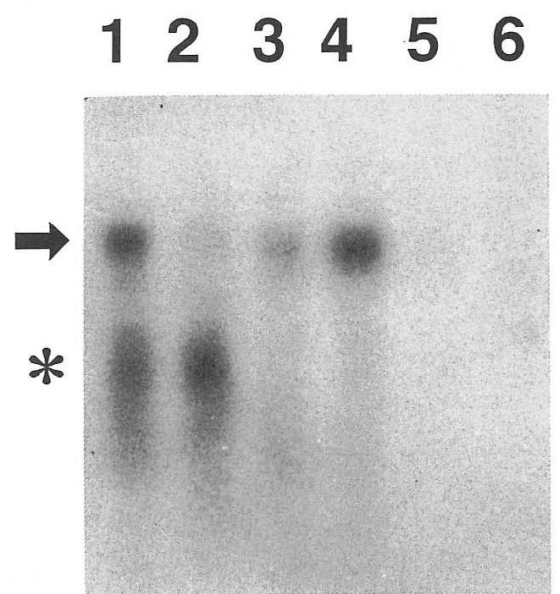

Fig. 3. Northern analysis of total RNA prepared from resistant (lanes 1 and 2), susceptible (lanes 3 and 4) and wild-type (lanes 5 and 6 ) plants. Lanes 1 , 3 and 5 are from the inoculated leaves and lanes 2, 4 and 6 are from the upper noninoculated leaves. Total RNA was extracted 7 days after inoculation, and then the transgene transcripts were detected with the digoxigeninlabeled oligonucleotide probe complementary to the $5^{\prime}$-untranslatable sequence of the transgene. The position corresponding to the intact transgene transcripts is indicated by an arrow and their degraded products are marked by an asterisk.

degraded after CMV infection in resistant plants and not in susceptible plants. We suspected that the transgene transcripts in resistant plants were completely degraded at 8 days after inoculation, and so we further prepared the total RNA from a resistant and a susceptible plants 7 days after inoculation, and analyzed by Northern hybridization. Consequently, we succeeded to detect a considerable level of partially degraded transgene transcripts in both inoculated and upper leaves of a resistant plant (Fig. 3, lanes 1 and 2). In the upper non-inoculated leaves, only weak signal corresponding to intact transcripts was detected, indicating that the degradation activity was newly induced or strongly enhanced by virus infection in the resistant plant, especially in the upper non-inoculated leaves. The major band of degraded transcripts, indicated by an asterisk in Fig. 3, was detected at the size of $c a$. $0.5 \mathrm{~kb}$. The oligonucleotide probe used in the experiment is complementary to the $5^{\prime}$-untranslatable sequence of the transgene, and the major product correspond to the $5^{\prime}$-half of the transcript. The partial degradation might result from the structural change caused by the insertion of the ribozyme sequence into the middle of the transgene. In contrast, no degradation was observed in the susceptible plant (Fig. 3, lanes 3 and 4).

To confirm whether the degradation activity is specific to CMV RNA sequences, high concentrations (50 $\mu \mathrm{g} / \mathrm{ml}$ ) of purified CMV and peanut stunt virus (PSV), a cucumovirus closely related to $\mathrm{CMV}(\sim 65 \%$ 3a nu- 
Table 2. Virus accumulation in the excised upper leaves of resistant phenotype plants after challenge inoculation

\begin{tabular}{cccc}
\hline \hline \multirow{2}{*}{ Plant line $^{\text {a) }} \begin{array}{c}\text { Preinoculation } \\
\text { of CMV }\end{array}$} & \multicolumn{2}{c}{ Challenge inoculation ${ }^{\mathrm{c})}$} \\
\cline { 3 - 4 } & + & $\mathrm{CMV}$ & $\mathrm{PSV}$ \\
\hline Rz204-6 & - & $0.016 \pm 0.005^{\mathrm{d}}$ & $1.228 \pm 0.038$ \\
Rz204-6 & - & $1.237 \pm 0.008$ & $1.125 \pm 0.105$ \\
Control & - & 1.281 & $1.281 \pm 0.008$ \\
\hline
\end{tabular}

a) Four plants were used in each treatment. Rz204-6 plants are homozygous R2 progeny of Rz204. Plants transformed with firefly luciferase gene were used as control.

b) Four Rz204-6 plants were preinoculated with $1: 100$ diluted CMV-infected tobacco sap on 6th leaves.

c) Eight days after preinoculation, excised 10th leaves were inoculated with purified virus preparations (50 $\mu \mathrm{g}$ ) $\mathrm{ml})$.

d) ELISA values (mean \pm S.E.) 4 days after challenge inoculation.

cleotide sequence homology), were inoculated with the excised upper (10th) leaves of "highly" resistant plants, which were free from systemic infection of CMV. Four days after inoculation, viral accumulation was checked by ELISA. CMV accumulation was not observed in resistant plant leaves, although PSV was propagated as high level as in control plant leaves (Table 2). This suggests that the degradation activity induced or enhanced in resistant plants is highly specific to transgene sequences, that is, complementary $3 \mathrm{a}$ gene of CMV.

From these results, we concluded that the extreme resistance observed in resistant phenotype plants is possibly involved in the targeted elimination of RNA. That is, RNA degradation targeted to specific RNA sequences (complementary 3a gene) had been newly induced or strongly enhanced by CMV infection, so that complementary strand of CMV RNA3 as well as transgene RNA would be degraded.

This phenomenon is similar to that in the sense RNA-mediated resistance in potyvirus reported by Dougherty and co-workers ${ }^{2,6,11)}$. In their reports, untranslatable $\mathrm{CP}$ gene were constructed and introduced into tobacco, so that transgenic plants displaying. "highly resistant" or "recovered" phenotype were obtained. In the case of antisense construct of PVY CP gene, "highly resistance" or "resistant" plants were not produced ${ }^{11)}$. In our experiments, the resistant phenotype was not found in simple antisense RNA-expressing or translatable CMV CP-expressing plants ${ }^{8)}$, and no degraded products of transgene transcripts were found in virus-inoculated plants (data not shown). Therefore, the qualitative aspects, aberrant ribozyme sequences and/or its secondary structure, may influence the activation of the targeted RNA elimination.

Transgene inactivation is often caused by multiple transgene integration, and the phenomenon is also related to the zygosity ${ }^{3)}$. Indeed, all of Rz204-6 plants tested, one of homozygous R2 line generated from
Rz204, showed resistant phenotype (data not shown). Rz204-1 (R2) plants used in this study are thought to possess the transgene at one locus and to consist of both homozygous and hemizygous states from their sensitivity to kanamycin. As mentioned above, the ratio of resistant phenotype to susceptible phenotype is $32: 8$, which does not coincide with the ratio of homozygous to hemizygous in theory $1: 2$. This indicates that the zygosity is not an only determinant of the transgene inactivation.

This is the first report, to our knowledge, that directly showed the degradation of transgene RNA in virusresistant transgenic plants. Transgene inactivation is common phenomenon in most eukaryotic cells. In plants, the reports on transgene inactivation have been increased $^{3,4)}$, and it has been a severe problem for genetic engineering of plants. On the other hand, cosuppression-like inactivation are available for crop protection against viruses, but the mechanism on the degradation of exogenous RNA remained unknown.

We thank Dr. M. Ohshima for helpful advice, and Dr. P. Annamalai for critical reading of the manuscript. We also thank Dr. Y. Ehara, Tohoku Univ., for kind gifts of CMV-Y and PSV-J.

\section{Literature cited}

1. Chomcznski, P. and Sacchi, N. (1987). Single-step method of RNA isolation by acid guanidium thiocyanate-phenol-chloroform extraction. Anal. Biochem. 162 : 156-159.

2. Dougherty, W.G., Lindbo, J.A., Smith, H.A., Parks, T.D., Swaney, S. and Proebsting, W.M. (1994). RNAmediated virus resistance in transgenic plants: Exploitation of a cellular pathway possibly involved in RNA degradation. Mol. Plant-Micorbe Interact. 7 : 544-552.

3. Finnegen, J. and McElroy, D. (1994). Transgene inactivation : plant fight back! Bio/Technology 12 : 883888.

4. Flavell, R.B. (1994). Inactivation of gene expression in plants as a consequence of specific sequence duplication. Proc. Natl. Acad. Sci. USA 91: 3490-3496.

5. Hammond, J. and Lawson, R.H. (1988). An improved purification procedure for preparing potyvirus and cytoplasmic inclusions from the same tissue. J. Virol. Methods 20 : 203-217.

6. Lindbo, J.A., Silva-Rosales, L., Proebsting, W.M. and Dougherty, W.G. (1993). Induction of highly specific antiviral state in transgenic plants: Implications for regulation of gene expression and virus resistance. Plant Cell 5 : 1749-1759.

7. Nakamura, S., Honkura, R., Ugaki, M., Ohshima, M. and Ohashi, Y. (1994). Nucleotide sequence of the $3^{\prime}$ terminal region of bean yellow mosaic virus RNA and resistant to viral infection in transgenic Nicotiana benthamiana expressing its coat protein gene. Ann. Phytopathol. Soc. Jpn. 60 : 295-304.

8. Nakamura, S., Honkura, R., Ugaki, M., Ohshima, M. and Ohashi, Y. (1995). Resistance to viral infection in 
transgenic plants expressing ribozymes designed against cucumber mosaic virus RNA3. Ann. Phytopathol. Soc. Jpn. $61: 53-55$.

9. Powell-Abel, P., Nelson, R.S., De, B., Hoffman, N., Rogers, S.G., Fraley, R.T. and Beachy, R.N. (1986). Delay of disease development in transgenic plants that express the tobacco mosaic virus coat protein gene. Science 232: 738-743

10. Sambrook, J., Fritsch, E.F. and Maniatis, T. (1989). Molecular Cloning : A Laboratory Manual, 2nd ed., Cold Spring Harbor Laboratory, Cold Spring Harbor, New York.

11. Smith, H.A., Swaney, S.L., Parks, T.D., Wernsman, E.A. and Dougherty, W.G. (1994). Transgenic plant virus resistance mediated by untranslatable sense RNAs: expression, regulation, and fate of nonessential RNAs. Plant Cell $6:$ 1441-1453.

12. Sturtevant, A.P. and Beachy, R.N. (1992). Virus resistance in transgenic plants : Coat protein-mediated resistance. In Transgenic Plants: Fundamentals and Applicatons (Hiatt, A. ed.), Marcel Dekker, New York, pp. 93-112.
13. Wilson, T.M.A. (1993). Strategies to protect crop plants against viruses: Pathogen-derived resistance blossoms. Proc. Natl. Acad. Sci. USA 90 : 3134-3141.

\section{和 文 摘 要}

中村茂雄・本藏良三・岩井孝尚・宇垣正志・大橋祐子：ウイル 又抵抗性形質転換植物に扔ける導入遺伝子の分解

キュウリモザイクウイルス (CMV) RNA3 の 3a 遺伝子を切 断するようにデザインしたリボザイム（840 塩基の 3a アンチセ ンスを含む）導入形質転換夕バコの 1 系統の自殖後代において 著しい抵抗性のばらつきが観察された。これら抵抗性の強弱と 導入遺伝子転写産物の蓄積量との間に相関関係は認められなか った。特に強抵抗性個体においては, 接種後の上位葉から導入遺 伝子がほとんど検出されず，その部分分解産物が確認された。こ のことから, 強い CMV 抵抗性の要因は導入遺伝子の直接の働 きではなく，宿主細胞が導入遺伝子の配列に特異的な RNA 分 解活性を獲得した結果，導入遺伝子のみならず感染した CMV の RNA3 の相補鎖が分解され，ウイルス抵抗性が発現した可能 性が示された。

(Received June 19, 1995 ; Accepted December 28, 1995) 